Discussion Paper No. 17-023

\title{
Risk Attitudes, Job Mobility and Subsequent Wage Growth During the Early Career
}

Bethlehem A. Argaw, Michael F. Maier, and Olga J. Skriabikova

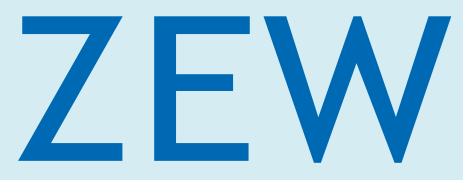

Zentrum für Europäische Wirtschaftsforschung $\mathrm{GmbH}$

Centre for European Economic Research 
Discussion Paper No. 17-023

\title{
Risk Attitudes, Job Mobility and Subsequent Wage Growth During the Early Career
}

\author{
Bethlehem A. Argaw, Michael F. Maier, \\ and Olga J. Skriabikova
}

Download this ZEW Discussion Paper from our ftp server:

http://ftp.zew.de/pub/zew-docs/dp/dp17023.pdf

Die Discussion Papers dienen einer möglichst schnellen Verbreitung von neueren Forschungsarbeiten des ZEW. Die Beiträge liegen in alleiniger Verantwortung der Autoren und stellen nicht notwendigerweise die Meinung des ZEW dar.

Discussion Papers are intended to make results of ZEW research promptly available to other economists in order to encourage discussion and suggestions for revisions. The authors are solely responsible for the contents which do not necessarily represent the opinion of the ZEW. 


\title{
Risk ATTITUDES, JOB MOBILITY AND SUBSEQUENT WAGE GROWTH DURING THE EARLY CAREER*
}

\author{
Bethlehem A. Argaw ${ }^{a}$ Michael F. Maier,${ }^{b}$ Olga J. Skriabikova ${ }^{c}$
}

April 4, 2017

\begin{abstract}
Job change is a decision under uncertainty: It is associated with costs whereas the decision is made without full knowledge about future benefits. In order to investigate the relationship between willingness to take risks and job mobility, we first extend a model for on-the-job search with nonwage job characteristics by including heterogeneity in risk attitudes. Second, we empirically test the model's implications showing that individuals who are more risk-averse choose to change their jobs less often than more risk-tolerant individuals. This difference in the job changing behaviour leads to only moderate differences wage growth during early career: Risk-averse individuals tend to have on average higher wage gains from each job change and have obtained higher overall wage growth at the end of the early career phase.
\end{abstract}

JEL classification: D81, J31, J62

Keywords: risk attitudes, job mobility, wage growth, early career development

\footnotetext{
* Bethlehem A. Argaw and Michael F. Maier gratefully acknowledge financial support from the German Ministry of Education and Research (BMBF) under grant 01PW11001 under the funding framework "The Economics of Science". The views expressed in this article are those of the authors and do not necessarily reflect the views of the BMBF. For helpful discussions, the authors would like to thank Thomas Dohmen, Bernd Fitzenberger, Susanne Steffes and participants at the Labour Markets, Human Resources and Social Policy department's seminar at the ZEW, AiO seminar at the School of Business and Economics (GSBE)-Maastricht University, GlaD PhD workshop at the University of Goettingen and participants at the SES, EALE, ESPE, EEA and the Annual Conference of the German Economic Association. We are grateful to Carla Krolage and Frederik Weber for excellent research assistance. Any remaining shortcomings are our sole responsibility.

${ }^{a}$ Leibniz University of Hanover (argaw@aoek.uni-hannover.de)

${ }^{b}$ Centre for European Economic Research (maier@zew.de)

${ }^{c}$ Provincie Limburg (oj.skriabikova@prvlimburg.nl)
} 


\section{Introduction}

The importance of job mobility for individuals' success in the labour market is widely discussed. The role of job changes particularly for wage growth has been extensively investigated in empirical analyses (e.g. Topel and Ward, 1992; Light and McGarry, 1998; Neumark, 2002). Job changes within an individual's first years in the labour market are important, as decisions made in this period can strongly influence longterm prospects (Topel and Ward, 1992; von Wachter and Bender, 2006; Möller and Umkehrer, 2014).

While search and matching theories specify the wage of the current and new job as determinants for job changes, a growing literature has demonstrated the relevance of nonwage job characteristics (e.g. Bonhomme and Jolivet, 2009, Sullivan and To, 2014; Bonhomme et al., 2015). Job characteristics other than the wage such as the possibility of promotion, actual hours worked, the flexibility of working time and other working conditions cannot be fully specified ex-ante in working contracts but reveal only after some time. Surprisingly, few studies on job mobility have investigated the importance of risk or uncertainty which individuals face when they decide whether or not to change their job. The study by van den Berg (1992), for example, examines different types of costs related to job changes such as the loss of fringe benefits, moving costs and costs with adjusting to a new environment. But even if these costs can be entirely foreseen by the individual at the time the decision is made, the individual's benefits from the job change are not fully determined ex-ante. To change one's job therefore involves risk, and individuals evaluate the expected utility from a job offer depending on their risk attitudes. Hence, risk-averse individuals should be less likely to change their job, ceteris paribus, because they are less willing than risk-tolerant individuals to bear the risk associated with a job change.

In this paper, we investigate the relationship between risk attitudes, job mobility and subsequent wage growth. We first extend the model for on-the-job search with nonwage job characteristics by including heterogeneity in risk attitudes across individuals. Based on this theoretical framework we empirically answer the question whether individuals who are more risk-averse change jobs less often during early career than individuals who are more risk-tolerant. We then examine whether job change decisions of risk-averse and risk-tolerant individuals lead to different patterns of wage growth during early career.

Taking risk aversion into account provides several explanations for differences in the relationship between job mobility and wage growth. A reason for differences in wage growth with each job change may be that risk-averse individuals demand greater immediate compensation in terms of the contracted wage in the new job for the risk associated with the job change. As a result, when risk-averse individuals actually change their job, the accompanied increase in the wage level is higher 
than for risk-tolerant individuals. Furthermore wage growth can also be explained by the number of job changes undertaken by risk-averse and risk-tolerant individuals during early career. Fewer job changes means an increase in tenure and risk-averse individuals might thus receive comparably higher returns from accumulated firm-specific capital. On the other hand, the match quality of the job and thus wage growth within the job cannot be entirely foreseen ex-ante. Risk-averse individuals who change jobs less frequently, have fewer opportunities to learn about their own abilities and preferences because they obtain less information with respect to their fit to different job requirements (Farber and Gibbons, 1996; Antonovics and Golan, 2012, Papageorgiou, 2014).

Our empirical results show firstly that risk-averse individuals change jobs less often during early career than risk-tolerant individuals. Secondly, wage gains from each job change tend to be on average higher for risk-averse individuals which is in line with the argument that risk-averse individuals demand higher monetary compensation with each job change. Furthermore, the difference in job changing behaviour between risk-averse and risk-tolerant individuals during early career leads to overall higher wages for risk-averse individuals. As a conclusion, our findings indicate that the assumption of homogeneous risk attitudes commonly made in theoretical as well as empirical studies on job mobility and wage growth can not be consistently supported.

In accordance with our two research questions this paper is related to two literature strands. First, the analysis contributes to studies which investigate the influence of risk attitudes on labour market decisions. This comprises of studies on the role of risk attitudes in the decision to invest in human capital and its related returns (Shaw, 1996, Brown and Taylor, 2005; Budria et al., 2012), in the decision to become self-employed (Caliendo et al., 2009; Fossen, 2011; Skriabikova et al., 2014) and in sorting into occupations (Fuchs-Schündeln and Schündeln, 2005, Bonin et al., 2007). Second, our study is related to literature which investigates the relationship between job mobility and wage growth. While there is much evidence that job mobility is related to positive wage growth (e. g. Bartel and Borjas, 1981, Topel and Ward, 1992, Dustmann and Meghir, 2005), some studies have also found a negative relationship between job mobility and wage growth (e. g. Light and McGarry, 1998; Neumark, 2002). We therefore contribute to this literature by investigating how the introduction of heterogeneous risk attitudes influences the relationship between job mobility and wage growth.

The paper proceeds as follows. In section 2 we sketch our conceptual framework in order to explain why risk attitudes affect job changes and how the relationship between job changes and associated wage growth depends on the individual's willingness to take risks. In section 3 , our empirical approach and the data are described. Section 4 presents our main findings and sensitivity analyses. The last section provides a conclusion. 


\section{Conceptual framework}

In the following, we present a theoretical model that formalises the relationship between risk attitudes and job mobility. In the canonical on-the-job search model (Burdett, 1978; Mortensen, 1986), a worker changes her job based on the comparison of the current wage and the offered wage of the new job. Hwang et al. (1998) introduce nonwage components in the on-the-job search framework indicating that alongside wages, other job characteristics might also be important for on-the-job search. Such characteristics include working time, hours worked, the working environment and working conditions. Subsequent empirical analysis has confirmed the importance of nonwage job characteristics in individuals' decision to change jobs. (e.g. Bonhomme and Jolivet, 2009, Sullivan and To, 2014, Bonhomme et al. 2015).

We extend the recent on-the-job search model provided by Sullivan and To (2014), which includes nonwage job characteristics. We incorporate individual risk attitudes in the model to consider a worker's uncertainty about the utility of nonwage characteristics when deciding whether or not to accept a job offer. We display the discounted expected value of lifetime utility for a worker in her current job as:

$$
V_{e}\left(U_{0}\right)=U+q\left[V_{u}-V_{e}\left(U_{0}\right)\right]+\delta\left[\lambda \mathbf{E} \max \left\{V_{e}\left(U_{1}\right), V_{e}\left(U_{0}\right)\right\}\right]
$$

Unlike the canonical on-the-job search model, the utility from employment $U$ is determined by the wage $w$ and the utility from nonwage job characteristics $\omega$ :

$$
U=g(w, \omega)
$$

New job offers arrive at a rate of $\lambda$ as a random draw $(w, \omega)$ from the joint distribution $F(w, \omega)$. Workers decide whether or not to change their job evaluating the discounted expected value of lifetime utility of the current job $V_{e}\left(U_{0}\right)$ and of the job offer $V_{e}\left(U_{1}\right)$. As in the canonical on-the-job search model, $V_{u}$ is the expected utility of unemployment where $q$ is the job destruction rate.

Individuals change their job if the utility level of the offered job is greater than the utility level of the current job $\left(U_{1}>U_{0}\right) !^{1}$ In this case, the offer exceeds the reservation utility $U_{r}$ such that

$$
V_{e}\left(U_{1}\right) \geq V_{e}\left(U_{r}\right)
$$

To introduce heterogeneity in risk attitudes in the model we define the parameter $\pi$ which measures an individual's degree of risk aversion. For ease of presentation, we specify that the individual having the degree of risk aversion $\pi_{1}$ is more risk averse than the individual with the degree of risk

\footnotetext{
${ }^{1}$ We assume that $V_{e}(U)$ is strictly increasing in $U$.
} 
aversion $\pi_{2}$ :

$$
\pi_{1}>\pi_{2}, \pi_{1}, \pi_{2} \in \Pi
$$

The expected utility of a new job is evaluated differently by individuals according to their risk aversion. To incorporate risk attitude in the on-the-job search model, we augment the reservation utility by a risk premium $P$ which depends on the degree of risk aversion $\pi$

$$
V_{e}\left(U_{r}\right)=V_{e}(U)+P(\pi)
$$

The discounted value of employment for an employed person changes to

$$
\left.V_{e}\left(U_{0}\right)=U+q\left[V_{u}-V_{e}\left(U_{0}\right)\right]+\delta\left[\lambda \mathbf{E} \max V_{e}\left(U_{1}\right)-P(\pi), V_{e}\left(U_{0}\right)\right\}\right]
$$

Individuals change their job only if the expected utility of the job offer exceeds the expected utility of their current job by the risk premium $P(\pi)$. From this we can derive the exit rate from the current job:

$$
\theta\left(U_{0}, U_{1}, \pi\right)=\lambda \mathbb{1}\left[V_{e}\left(U_{1}\right)>V_{e}\left(U_{0}\right)+P(\pi)\right]
$$

Our main hypothesis derived from the theoretical considerations is that more risk-averse individuals change their jobs less often than less risk-averse individuals. In the empirical part of this study, we explicitly test this hypothesis for individuals in their early career.

Our exploration of the relationship between risk attitudes and job mobility has important implications for the question as to how job mobility influences wage growth. From a theoretical perspective, there is disagreement as to whether job-to-job transitions yield positive wage growth. On the one hand, on-the-job search theory predicts that individuals change their job only if a wage offer exceeds the wage of their current job. This predicts that job-to-job transitions will result in positive wage growth (Burdett, 1978; Jovanovic, 1979a). On the other hand, matching models allow the possibility of negative wage growth (Jovanovic, 1979b). Based on the assumption that the quality of a job match only reveals itself after an individual has been working in a job for some time, wage growth related to job-to-job transitions can cease or even be negative.

The introduction of risk attitudes into these models creates several hypotheses on the relationship between job mobility and wage growth. Firstly, if we assume that the uncertain utility of a job is related only to the nonwage job characteristics $\omega$, the contracted wage of the new job can be considered as compensation for this uncertainty 2 Realised wage growth accompanying each job

\footnotetext{
${ }^{2}$ For this argument, we have to make an assumption on the shape of the utility function which in turn determines the
} 
change should therefore be higher for more risk-averse individuals. This is because they require more compensation for having chosen a risky alternative than less risk-averse individuals.

Secondly, on the other hand, if we consider wage growth in the current job, the influence of job mobility in association with risk attitudes is predicted to be negative. As risk-averse individuals are more reluctant to change their job $\left(\theta_{1}\left(U_{0}, U_{1}, \pi_{1}\right)<\theta_{2}\left(U_{0}, U_{1}, \pi_{2}\right)\right)$, they might tolerate less or no wage growth for a longer time than risk-tolerant individuals.

Modelling the frequency of job changes during individuals' early career by differences in risk attitudes, comes with an ambiguous derivation with respect to overall wage growth during that period. A lower frequency of job changes can lead to higher wage growth due to returns from accumulated firm-specific capital. On the other hand, the job changing behaviour of more risk-averse individuals provides fewer opportunities for individuals to learn about their abilities and preferences by having experienced different jobs. Wage growth for more risk-averse individuals could therefore be lower, as with each job change the individual can gain returns from information thereby increasing job match quality via learning (Farber and Gibbons, 1996; Antonovics and Golan, 2012; Papageorgiou, 2014 .

In view of the ambiguity of the theoretical predictions, we empirically investigate in the following the relationship between job mobility and wage growth accounting for risk attitudes. On the basis of the empirical relation between risk attitudes and job mobility, we analyse the influence of risk attitudes and wage growth associated with each job change as well as the overall wage growth during the early career.

\section{Variable specification and sample construction}

The empirical analysis draws on data from the German Socio-Economic Panel Survey (SOEP). The SOEP is a representative household panel survey which is conducted on an annual basis (see Wagner et al. (2007) for details). Our analysis contains individuals observed entering the labour market in the SOEP since 1992. We consider individuals who entered the labour market as full-time or regular part-time employees disregarding individuals with student jobs or in other irregular types of employment. Individuals who were below 18 or above 32 years of age at the time of entry, as well as those who were self-employed when entering the labour market are excluded from the analysis.

sign of $P\left(\pi_{i}\right)$. If individuals are more or less risk-averse $\left(P\left(\pi_{i}\right)>0\right)$, a certain disutility from facing risks exists for all individuals and individuals want to be compensated when facing risk. In contrast, it could be that individuals are more or less risk-tolerant $\left(P\left(\pi_{i}\right)<0\right)$, and hence are to some extent willing to pay for opportunities associated with higher risks. In the latter case, these would mean in our context that individuals favour risks associated with a job change. Deciding to change the job because it is associated with higher risks, has been described as job shopping (Johnson, 1978, McGoldrick and Robst, 1996) or experimenting on job choice (Antonovics and Golan. 2012). Presenting our reasoning we assume that all individuals are more or less risk-averse. The empirical analysis will test this assumption. 
The first variable of interest is the total number of job changes that individuals experience during their first seven years in the labour market. The variable is measured using the survey question on whether respondents have started a new job since the previous interview. Our focus is on voluntary job changes, i.e. job changes that are initiated by the worker. We focus on voluntary job changes since there is no clear theoretical prediction on the relationship between risk attitude and involuntary jobs changes and the subsequent wage growth. We distinguish voluntary from involuntary job changes on the basis of the unemployment duration which workers experience between jobs, as in Perez and Sanz (2005) and Pavlopoulos et al. (2014). We consider a job change as voluntary if workers experience a maximum of three months of unemployment after having left a job.

Alternatively, one can distinguish between voluntary and involuntary job changes based on the reasons provided by respondents for changing job (Hunt, 2001; Fuller, 2008). The data on the reasons of job changes unfortunately contains a substantial amount of missing information. We therefore test the robustness of the results by defining a job change as voluntary if a worker experience a maximum of three months of unemployment as part of changing job and has changed job for reasons other than termination of employment by the employer or company closure. Of those changing jobs and stating the reason for a job change, 18 percent specify "terminated by employer" and "company closed down" as the reasons for changing job.

Our measure of job change comprises voluntary job changes within and across firms, industries and/or occupations. The risk associated with changing jobs across firms, industries and/or occupations is likely to be greater than that associated with job changes within the same firm, industry and/or occupation. Survey respondents were therefore asked whether they changed jobs within the same firm or across firms. Of those changing jobs and providing information, 63 percent change to a new firm and 10 percent stay in the firm. Given the sample size, it is not possible to analyse job changes within and across firms, industries and occupations separately. Instead we include industry and occupation fixed effects in all regressions.

The second variable of interest is willingness to take risks. We specifically use willingness to take risk in occupational matters which was surveyed in the years 2004 and 2009. The variable is measured on a scale from zero to ten, in which higher values reflect greater willingness to take risks $3^{3}$ For ease of interpretation, we define a binary risk attitude measure by grouping individuals with risk attitude below the median as risk-averse, and those with risk attitude above the median as more risk-tolerant.

3 The exact wording of the question, translated from German, reads: "People can behave differently in different situations. How would you rate your willingness to take risks in the following areas? How is it in your occupation? Please give me a number from 0 to 10 , where the value 0 means: "Risk-averse" and the value 10 means: "Fully prepared to take risks". You can use the values in between to make your estimate." Dohmen et al. (2011) have shown that this question is significantly related to paid lottery choices, and explains behaviour in a range of important domains of real life decisions. 
A recent strand in the literature addresses the stability of individuals' risk preferences over time using measures based on subjective assessments and (hypothetical and incentivised) lottery choices (e.g. Harrison et al. (2005); Sahm (2007); Andersen et al. (2008); Baucells and Villasís (2009); Reynaud and Couture (2010)). These studies do not find evidence for systematic changes in a individual's risk preferences, except in relation to age. Sahm (2007), for example, reports a general increase in risk aversion with age, but finds that risk preferences are rank-order stable. Dohmen et al. (2012b) also provide evidence that risk attitudes measured by the survey question which we use in this study, are generally stable. $4^{4}$

There is no widely accepted concept that captures 'early career'. Topel and Ward $(1992)$ and Manning and Swaffield (2008), for example, define early career as the first ten years after labour market entry. Other studies consider the first five years (Neumark, 2002), seven years (Johnson, 1978) or combinations (Light and McGarry, 1998). We define 'early career' as the first seven years following labour market entry in order to have sufficient incidence of job mobility and number of observations for the analysis.

Ideally, we use for the empirical analysis a sample of individuals with the same degree of labour market attachment during the first seven years in the labour market. Therefore we consider only individuals who were employed at each interview conducted during their first seven years. This sample contains 280 observations:5 To investigate the sensitivity of our results to sample size, we construct another sample including also individuals who might be unemployed or out of labour force at the day the interview is conducted. This sample is less restrictive and contains 1380 observations.

Table B.2 gives a descriptive overview of the differences between both samples. 59 percent of individuals who are consecutively employed over the first seven years in the labour market change their job voluntarily at least once. When adding individuals with employment gaps during the first seven years in the labour market to the sample, the share drops to 37 percent. This could represent a mechanical effect, because job changes can naturally only be observed when an individual is employed. Accordingly, the average number of job changes is smaller in the less restrictive sample. However, the average number of job changes among those who changed their job at least once is roughly equal between the two samples. In summary, the less restrictive sample is more heterogeneous concerning the incidence of job changes in early career. Whenever we use the non-restrictive sample in the following empirical analysis, we therefore include an indicator for an individual's number of employment gaps during early career.

Other characteristics depict differences in labour market attachment between the two samples.

\footnotetext{
${ }^{4}$ In our restrictive sample the mean and median differences between reported risk attitude in 2004 and 2009 is 0.60 and 1 respectively. When we define risk attitude as a binary indicator for risk aversion, the mean and median difference between 2004 and 2009 is zero. This implies that a person's risk attitude is generally stable over the period of time relevant for our study.

5 Table B.1 describes the step-by-step sample selection procedure.
} 
Individuals with employment gaps in the first seven years are less educated, are more likely to hold a first job in part-time with a temporary contract, have lower tenure and get a lower wage in first job. However, socio-demographic characteristics and risk aversion are comparable between the two samples.

\section{Results}

\subsection{The influence of risk attitudes on voluntary job changes}

In a first step we want to clarify whether there is a significant relationship between risk attitudes and the number of job changes an individuals makes in her early career. Our conceptual framework postulates that risk-averse individuals change jobs less often than risk-tolerant individuals. Descriptive evidence indeed shows that the group of risk-averse individuals change jobs voluntarily on average 0.69 times during the first seven years in the labour market whereas risk-tolerant individuals change jobs voluntarily on average one time. This result is visualised in Figure 1 depicting differences in the average number of voluntary job changes between the group of risk-averse and risk-tolerant individuals over the first seven years. The gap in the number of job changes between both groups widens with the years of potential experience in the labour market increasing.

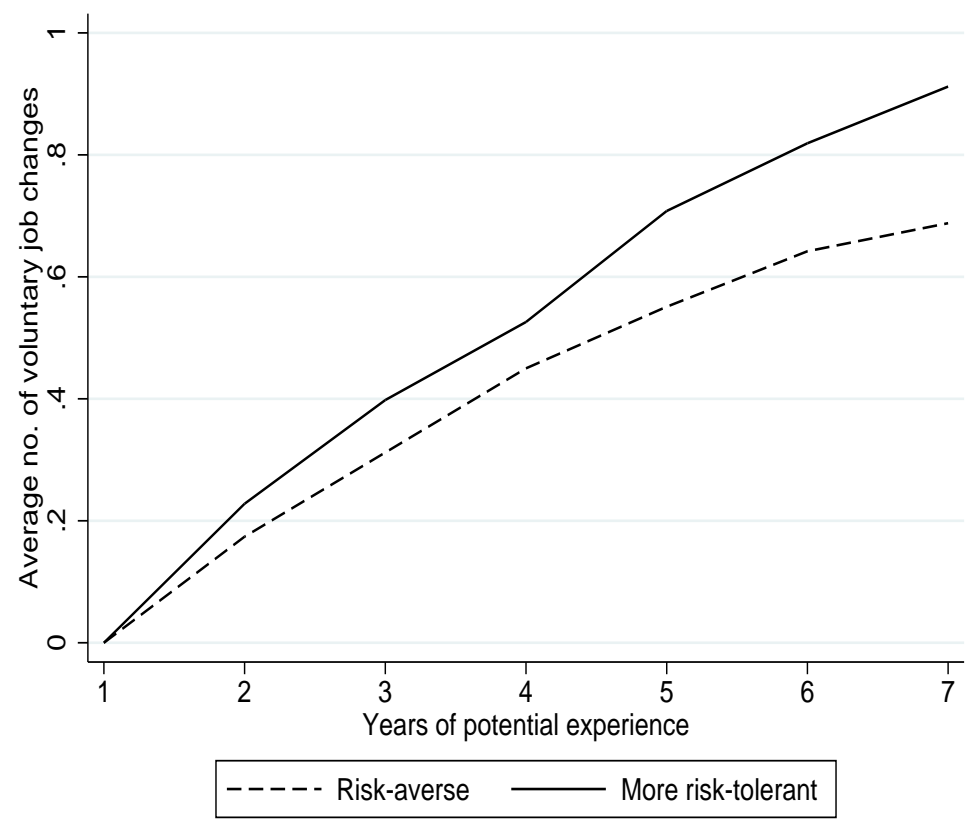

Figure 1: Average number of voluntary job changes during the early career by level of risk aversion. 
To examine the significance of the relationship between risk attitudes and job mobility during the early career we use the following econometric specification:

$$
T J C_{i}=\alpha_{0}+\alpha_{1} R A_{i}+\delta X_{i}+\mu_{i}
$$

$T J C_{i}$ is the total number of voluntary job changes during the first seven years in the labour market. $R A_{i}$ is a binary measure of risk attitude which takes the value one if individual $i$ 's risk attitude is below the median of the distribution. $X_{i}$ includes other control variables which we will discuss below. $\mu_{i}$ is an error term. The coefficient of interest is $\alpha_{1}$ which indicates the influence of risk attitude on the total number of voluntary job changes.

We use an OLS regression to estimate equation (8). $\alpha_{1}$ gives a consistent estimate of the effect of risk attitude on the number of voluntary job changes under the assumption that risk attitude is uncorrelated with $\mu_{i}$. Therefore, $X_{i}$ includes various variables which are related to risk attitudes and at the same might influence job changing behaviour. This rules out that there any unobserved factors left which determine the relationship between risk attitudes and job changing behaviour and supports the causal interpretation of the estimation results.

First, individuals who experience a good match in their first job, in terms of productivity and preferences, are less likely to change jobs than individuals who experience a bad match. To rule out the possibility that job match systematically differs between risk-averse and risk-tolerant individuals, we also control for the wage and job satisfaction in the first job. In addition, we include the type of contract (temporary or permanent), the type of employment (part-time or full-time), previous experience within the firm and the size of the firm on labour market entry in the regression.

Second, previous studies have shown that individuals with higher levels of risk tolerance invest more in human capital (Brown and Taylor, 2005; Budria et al., 2012), and choose occupations with higher earnings variance (Bonin et al., 2007; Skriabikova et al., 2013) whereas risk-averse individuals are more likely to choose employment positions in the public sector ( $\overline{\text { Pfeifer, }}, 2010)$. We account for these differences by including the highest educational degree obtained and the following factors describing initial sorting: whether one is employed in the public or private sector, the occupationspecific earnings variance at the 2-digit level as well as occupation and industry fixed effects at the 1-digit level for the first job.

Third, risk attitudes can be transmitted from parents to their children (Dohmen et al., 2012a; Necker and Voskort, 2014). At the same time, the family background can affect the job changing behaviour, for example by providing job opportunities. Furthermore, individuals with a wealthy family background might evaluate job changing decisions as less risky than individuals with poorer family background. We therefore use the level of paternal education and parents' occupations to 
control for the intergenerational link of risk attitudes and the possibility that family background influences job changing behaviour.

Overall, the result is in line with our theoretical prediction supporting the proposition that riskaverse individuals make fewer number of voluntary job changes than risk-tolerant individuals. In Table 1, column (1), the simple correlation between risk attitude and the number of job changes is displayed. The coefficient on risk attitude is negative and remains significant when we add control variables for basic demographic and socio-economic characteristics, family background as well as year dummies in column (2).

The coefficient on risk attitude also remains negative when we include control variables describing initial match quality and initial sorting in columns (3), (4) and (5). For example, adding fixed effects at the 1-digit level for the industry and occupation in the first job on labour market entry job does not change the significance of the estimated coefficient on risk attitude. This implies that risk attitude is significant for voluntary job changes within as well as across industries and occupations.

The magnitude of the effect of risk attitude in column (5) can be interpreted the following way: Being risk-averse in occupational matters reduces the average number of job change made during the first seven years in the labour market by 0.276 , which is one third of a standard deviation. ${ }^{6}$

Other variables do not play a role in explaining the number of job changes during early career except for the wage level in the first job. The higher the wage in the first job the lower is the number of job changes during early career, which holds across all specifications. This result is in line with the theoretical literature on job-search models. Individuals change jobs only if the offered wage associated with a new job is high enough compared to the wage level in the current job. Our result therefore shows that risk attitudes explain job changing behaviour in addition to the level of the reservation wage.

\footnotetext{
${ }^{6}$ As robustness checks we run a Poisson regression to account for the distribution of the dependent variable which can only take on integer values from zero to seven. We also estimate an ordered logit model specifying a job change variable with categories for no job change, one job change, two or more job changes. In both cases risk-averse individuals change significantly less often their jobs during early career.
} 
Table 1: The influence of risk attitude on total number of job changes

\begin{tabular}{|c|c|c|c|c|c|}
\hline & $(1)$ & $(2)$ & $(3)$ & $(4)$ & $(5)$ \\
\hline 1 if Risk-averse & $\begin{array}{c}-0.224^{* *} \\
(0.099)\end{array}$ & $\begin{array}{c}-0.246^{* *} \\
(0.100)\end{array}$ & $\begin{array}{c}-0.252^{* *} \\
(0.102)\end{array}$ & $\begin{array}{c}-0.262^{* *} \\
(0.102)\end{array}$ & $\begin{array}{c}-0.276^{* *} \\
(0.109)\end{array}$ \\
\hline 1 if Male & & $\begin{array}{l}-0.098 \\
(0.101)\end{array}$ & $\begin{array}{l}-0.089 \\
(0.111)\end{array}$ & $\begin{array}{l}-0.065 \\
(0.112)\end{array}$ & $\begin{array}{l}-0.068 \\
(0.125)\end{array}$ \\
\hline 1 if Originates from West Germany & & $\begin{array}{c}0.055 \\
(0.126)\end{array}$ & $\begin{array}{c}0.021 \\
(0.123)\end{array}$ & $\begin{array}{c}0.042 \\
(0.126)\end{array}$ & $\begin{array}{l}-0.029 \\
(0.126)\end{array}$ \\
\hline 1 if German national & & $\begin{array}{c}0.213 \\
(0.139)\end{array}$ & $\begin{array}{c}0.134 \\
(0.172)\end{array}$ & $\begin{array}{c}0.154 \\
(0.184)\end{array}$ & $\begin{array}{c}0.074 \\
(0.189)\end{array}$ \\
\hline 1 if Low or no educational degree & & $\begin{array}{c}0.016 \\
(0.214)\end{array}$ & $\begin{array}{l}-0.002 \\
(0.231)\end{array}$ & $\begin{array}{l}-0.075 \\
(0.231)\end{array}$ & $\begin{array}{l}-0.013 \\
(0.223)\end{array}$ \\
\hline 1 if Tertiary educational degree & & $\begin{array}{c}0.249 \\
(0.154)\end{array}$ & $\begin{array}{c}0.226 \\
(0.169)\end{array}$ & $\begin{array}{c}0.246 \\
(0.176)\end{array}$ & $\begin{array}{c}0.090 \\
(0.214)\end{array}$ \\
\hline Age starting first job & & $\begin{array}{l}-0.024 \\
(0.022)\end{array}$ & $\begin{array}{l}-0.027 \\
(0.024)\end{array}$ & $\begin{array}{l}-0.027 \\
(0.024)\end{array}$ & $\begin{array}{l}-0.028 \\
(0.024)\end{array}$ \\
\hline Wage in first job & & & $\begin{array}{c}-0.253^{*} \\
(0.141)\end{array}$ & $\begin{array}{c}-0.243^{*} \\
(0.136)\end{array}$ & $\begin{array}{c}-0.244^{*} \\
(0.134)\end{array}$ \\
\hline Job satisfaction in first job & & & $\begin{array}{l}-0.031 \\
(0.025)\end{array}$ & $\begin{array}{l}-0.029 \\
(0.026)\end{array}$ & $\begin{array}{l}-0.032 \\
(0.026)\end{array}$ \\
\hline 1 if First job in public sector & & & $\begin{array}{l}-0.016 \\
(0.126)\end{array}$ & $\begin{array}{c}0.036 \\
(0.144)\end{array}$ & $\begin{array}{l}-0.038 \\
(0.150)\end{array}$ \\
\hline 1 if Permanent contract in first job & & & $\begin{array}{l}-0.066 \\
(0.113)\end{array}$ & $\begin{array}{l}-0.110 \\
(0.118)\end{array}$ & $\begin{array}{l}-0.117 \\
(0.121)\end{array}$ \\
\hline 1 if Part-time employment in first job & & & $\begin{array}{c}0.004 \\
(0.163)\end{array}$ & $\begin{array}{l}-0.069 \\
(0.156)\end{array}$ & $\begin{array}{l}-0.074 \\
(0.156)\end{array}$ \\
\hline Tenure in first job & & & $\begin{array}{l}-0.052 \\
(0.044)\end{array}$ & $\begin{array}{l}-0.044 \\
(0.045)\end{array}$ & $\begin{array}{l}-0.047 \\
(0.045)\end{array}$ \\
\hline Wage variance within occ. of first job & & & $\begin{array}{l}-0.311 \\
(0.757)\end{array}$ & $\begin{array}{l}-0.643 \\
(0.197)\end{array}$ & $\begin{array}{l}-0.034 \\
(1.034)\end{array}$ \\
\hline Constant & $\begin{array}{c}0.912^{* * *} \\
(0.067)\end{array}$ & $\begin{array}{c}1.265^{* * *} \\
(0.485)\end{array}$ & $\begin{array}{c}3.657^{* * *} \\
(1.239)\end{array}$ & $\begin{array}{c}3.872^{* * *} \\
(1.200)\end{array}$ & $\begin{array}{c}3.893^{* * *} \\
(1.342)\end{array}$ \\
\hline Year dummies & & $\sqrt{ }$ & $\sqrt{ }$ & $\sqrt{ }$ & $\sqrt{ }$ \\
\hline Parental background & & $\sqrt{ }$ & $\sqrt{ }$ & $\sqrt{ }$ & $\sqrt{ }$ \\
\hline Industry dummies and firm size & & & & $\sqrt{ }$ & $\sqrt{ }$ \\
\hline Occupation dummies & & & & & $\sqrt{ }$ \\
\hline R-squared & 0.017 & 0.041 & 0.113 & 0.141 & 0.182 \\
\hline Sample & 280 & 280 & 280 & 280 & 280 \\
\hline
\end{tabular}

Source: SOEP. Sample: labour market entrants. Dependent variable: total number of job changes during the first seven years in the labour market.

Notes: Heteroscedasticity-consistent standard errors are in parentheses. ${ }^{* *},{ }^{* *},{ }^{*}$ denote significance at the $0.01,0.05$, and 0.10 levels.

Table 2 provides estimation results for three robustness checks. Overall, the estimation results show that the effect of risk attitude remains negative and statistically significant. We examine the sensitivity of the results to sample size displaying results in columns (1) and (2). The estimations are based on the less restrictive sampling criteria which allows employment gaps during the first seven years. In columns (3) and (4), we show the estimation results when we additionally use information on the reasons for job changes as stated by respondents to define voluntary job change. 
Table 2: The influence of risk attitude on total number of job changes: Robustness checks

\begin{tabular}{|c|c|c|c|c|c|c|}
\hline & \multicolumn{2}{|c|}{$\begin{array}{l}\text { Non-restrictive } \\
\text { sample }\end{array}$} & \multicolumn{2}{|c|}{$\begin{array}{c}\text { Alternative definition of } \\
\text { voluntary job change }\end{array}$} & \multicolumn{2}{|c|}{$\begin{array}{c}\text { Labour market entry } \\
\text { after } 2000\end{array}$} \\
\hline & $(1)$ & $(2)$ & (3) & (4) & $(5)$ & $(6)$ \\
\hline 1 if Risk-averse & $\begin{array}{c}-0.103^{* * *} \\
(0.040)\end{array}$ & $\begin{array}{c}-0.087^{* *} \\
(0.036)\end{array}$ & $\begin{array}{c}-0.277^{* *} \\
(0.095)\end{array}$ & $\begin{array}{c}-0.381^{* * *} \\
(0.102)\end{array}$ & $\begin{array}{c}-0.302^{* *} \\
(0.127)\end{array}$ & $\begin{array}{c}-0.366^{* *} \\
(0.156)\end{array}$ \\
\hline 1 if Male & & $\begin{array}{l}0.073^{*} \\
(0.044)\end{array}$ & & $\begin{array}{l}-0.053 \\
(0.128)\end{array}$ & & $\begin{array}{l}-0.172 \\
(0.152)\end{array}$ \\
\hline 1 if Originates from West Germany & & $\begin{array}{c}0.009 \\
(0.042)\end{array}$ & & $\begin{array}{l}-0.014 \\
(0.132)\end{array}$ & & $\begin{array}{l}-0.052 \\
(0.122)\end{array}$ \\
\hline 1 if German national & & $\begin{array}{l}0.156^{* *} \\
(0.066)\end{array}$ & & $\begin{array}{l}-0.034 \\
(0.185)\end{array}$ & & $\begin{array}{c}0.122 \\
(0.281)\end{array}$ \\
\hline 1 if Low or no educational degree & & $\begin{array}{c}0.001 \\
(0.052)\end{array}$ & & $\begin{array}{c}0.003 \\
(0.235)\end{array}$ & & $\begin{array}{c}0.260 \\
(0.308)\end{array}$ \\
\hline 1 if Tertiary educational degree & & $\begin{array}{l}0.117^{*} \\
(0.065)\end{array}$ & & $\begin{array}{l}-0.024 \\
(0.189)\end{array}$ & & $\begin{array}{c}0.015 \\
(0.272)\end{array}$ \\
\hline Age starting first job & & $\begin{array}{c}-0.017^{* *} \\
(0.008)\end{array}$ & & $\begin{array}{l}-0.015 \\
(0.022)\end{array}$ & & $\begin{array}{c}0.006 \\
(0.034)\end{array}$ \\
\hline Wage in first job & & $\begin{array}{c}-0.123^{* * *} \\
(0.035)\end{array}$ & & $\begin{array}{l}-0.254^{*} \\
(0.136)\end{array}$ & & $\begin{array}{l}-0.125 \\
(0.174)\end{array}$ \\
\hline Job satisfaction in first job & & $\begin{array}{c}-0.019^{* *} \\
(0.009)\end{array}$ & & $\begin{array}{l}-0.048^{*} \\
(0.025)\end{array}$ & & $\begin{array}{l}-0.059^{*} \\
(0.034)\end{array}$ \\
\hline 1 if First job in public sector & & $\begin{array}{l}-0.075 \\
(0.055)\end{array}$ & & $\begin{array}{l}-0.025 \\
(0.142)\end{array}$ & & $\begin{array}{c}0.026 \\
(0.171)\end{array}$ \\
\hline 1 if Permanent contract in first job & & $\begin{array}{c}-0.037 \\
(0.040)\end{array}$ & & $\begin{array}{l}-0.123 \\
(0.114)\end{array}$ & & $\begin{array}{c}-0.262 \\
(0.159)\end{array}$ \\
\hline 1 if Part-time employment in first job & & $\begin{array}{c}-0.114^{* *} \\
(0.049)\end{array}$ & & $\begin{array}{l}-0.090 \\
(0.152)\end{array}$ & & $\begin{array}{l}-0.098 \\
(0.208)\end{array}$ \\
\hline Tenure in first job & & $\begin{array}{c}-0.037^{* * *} \\
(0.014)\end{array}$ & & $\begin{array}{l}-0.046 \\
(0.043)\end{array}$ & & $\begin{array}{l}-0.013 \\
(0.051)\end{array}$ \\
\hline Wage variance within occ. of first job & & $\begin{array}{c}0.758^{* *} \\
(0.312)\end{array}$ & & $\begin{array}{c}0.250 \\
(1.094)\end{array}$ & & $\begin{array}{l}-0.820 \\
(1.510)\end{array}$ \\
\hline Constant & $\begin{array}{c}0.538^{* * *} \\
(0.028)\end{array}$ & $\begin{array}{c}2.049^{* * *} \\
(0.351)\end{array}$ & $\begin{array}{c}0.847^{* * *} \\
(0.068)\end{array}$ & $\begin{array}{c}3.503^{* *} \\
(1.423)\end{array}$ & $\begin{array}{c}0.912^{* * *} \\
(0.086)\end{array}$ & $\begin{array}{c}3.024 \\
(1.875)\end{array}$ \\
\hline Year dummies & & $\sqrt{ }$ & & $\sqrt{ }$ & & $\sqrt{ }$ \\
\hline Parental background & & $\sqrt{ }$ & & $\sqrt{ }$ & & $\sqrt{ }$ \\
\hline Industry dummies and firm size & & $\sqrt{ }$ & & $\sqrt{ }$ & & $\sqrt{ }$ \\
\hline Occupation dummies & & $\sqrt{ }$ & & $\sqrt{ }$ & & $\sqrt{ }$ \\
\hline Employment gap dummies & $\sqrt{ }$ & $\sqrt{ }$ & & & & \\
\hline R-squared & 0.005 & 0.242 & 0.029 & 0.235 & 0.031 & 0.313 \\
\hline Sample & 1370 & 1370 & 257 & 257 & 166 & 166 \\
\hline
\end{tabular}

Source: SOEP. Sample: labour market entrants. Dependent variable: total number of job changes during the first seven years in the labour market.

Notes: Estimation method: OLS. Heteroscedasticity-consistent standard errors are in parentheses. $* * *, * *, *$ denote significance at the $0.01,0.05$, and 0.10 levels.

Finally, one might raise the concern that reverse causality produces a biased estimated of the coefficient on risk attitudes. It could be that individuals change their attitudes as a result of a job change rather than the other way around. Given that descriptive figures in section 3 show that risk attitudes in our sample are stable over time, we argue that this is of little concern. Yet, our sample 
includes some individuals who entered the labour market already in 1992. The survey question on risk attitudes was asked for the first time in 2004. We might therefore fail to observe adjustments in risk attitudes through the years 1992 to 2004 which could include a reversed causal direction of job changes affecting risk attitudes. To reduce that problem we use a sample of individuals who entered the labour market in the year 2000 or later in column (5). As a result, there are no changes to the main results in Table 1.

\subsection{Risk attitude, job changes and wage growth}

In the conceptual framework in section 2 we discuss three potential links between risk attitudes and wage growth associated with job changes. Firstly, risk-averse individuals demand a higher wage as compensation for the risk when they change job than risk-tolerant individuals. Secondly, risk-averse individuals are less likely to change their job than risk-tolerant individuals, given a constant job offer rate. Risk-averse individuals might therefore experience little or no wage growth in their current job for a longer period of time without changing jobs than more risk-tolerant individuals. Thirdly, risk-averse individuals change jobs less frequently during early career than risk-tolerant individuals and thus spend more years with the same firm. In terms of overall wage growth over the early career, risk-averse individuals might therefore obtain higher average returns to accumulated tenure. Changing jobs less frequently, risk-averse individuals may, on the other hand, receive less returns to information regarding the match between her preferences or abilities and job requirements than risk-tolerant individuals.

The described mechanisms propose an ambiguous relationship between risk attitudes and wage growth associated with job changes. Unfortunately, it is not possible to fully disentangle the three mechanisms in the empirical analysis. Yet, we are able to distinguish between the wage growth associated with each job change and overall wage growth as a result of the early career.

We therefore divide our empirical analysis on wage growth in two parts in order to examine the proposed mechanisms. In the first part, we apply the following wage growth equation in order to investigate whether wage gains accompanied by a voluntary job change are different between risk-averse and risk-tolerant individuals:

$$
\ln W_{i t}=\beta_{0}+\beta_{1} J C_{i t} \times R A_{i}+\theta Z_{i t}+\epsilon_{i t}
$$

$\ln W_{i t}$ is the $\log$ of real hourly wage at time $t . J C_{i}$ is an indicator variable for making a voluntary job change. We interact this variable with the binary, person-specific indicator for the attitude towards risks $R A_{i}$. $Z_{i t}$ includes time-variant individual and firm-level characteristics such as work experience, tenure, firm size, industry and occupation dummies. We estimate the wage growth equa- 
tion applying a fixed effect panel estimator. The advantage of the estimator is that any influence from time-invariant unobservable characteristics on voluntary job changes is removed without imposing any assumptions on the econometric specification. 7 We confine the estimation of equation (9) to individuals who voluntarily change job at least once during the first seven years in the labour market, in order to observe a homogenous group of individuals concerning job changing behaviour (cf. Bono and Vuri (2011)).

In the second part we examine whether overall wage growth related to job changing behaviour during early career is different between risk-averse and risk-tolerant individuals. For this purpose we estimate the following wage equation:

$$
\ln \Delta W_{i}=\beta_{0}+\beta_{1} T J C_{i} \times R A_{i}+\lambda Q_{i}+\epsilon_{i}
$$

$\ln \Delta W_{t}$ is the log of the real hourly wage difference between the first and seventh year in the labour market measuring overall wage growth during early career. $T J C_{i}$ is the number of job changes made voluntarily during early career interacted with the binary, person-specific indicator for the attitude towards risks $R A_{i}$. $Q_{i}$ includes demographic characteristics and variables representing parental background. These are variables which are determined previous to labour market entry. We do not include variables which are results of decisions taken while being in the labour market, such as characteristics of the first or the current job. This is because the simultaneous determination of (job choice) decisions and wage level could lead to biased estimations results 8

Table 3 presents the influence of risk attitudes on wage growth when changing the job. On average each voluntary job change is associated with a significant positive increase in log hourly real wages, irrespective of using the restrictive sample (columns (1) and (2)) or the non-restrictive sample (columns (3) and (4)). However, we only find a weakly significant difference in wage growth associated with a job change between risk-averse and risk-tolerant individuals when we use the nonrestrictive sample. Risk-averse individuals have on average higher wage growth when they change their job than risk-tolerant individuals.

Differences between the estimation results based on the restrictive sample and based on the nonrestrictive sample (Table 3) can, in this case, exist for two reasons: Firstly, the fixed effects panel estimator exploits the variation over time within each cross section and thus is relatively imprecise when regressors vary little over time. Although there is no difference in the shares of risk-averse and risk-tolerant individuals between both samples, the variation (over time) in job changes during the early career is higher in the non-restrictive sample (see descriptive statistics in Table B.2). This

\footnotetext{
7 Time-invariant unobservable characteristics might be in particular initial conditions when starting the career, sorting into specific jobs and parental background.

8 Angrist and Pischke (2009) discuss this problem under the term 'bad controls'. Including explanatory variables which might also represent dependent variables in the notional estimation specification leads to biased estimates.
} 
goes in hand with the fact that in the estimation based on the restrictive sample less of the variation across individuals is explained than in the estimation based on the non-restrictive sample.

Table 3: Influence of risk attitudes on the relationship between job change and wage growth

\begin{tabular}{|c|c|c|c|c|}
\hline & \multicolumn{2}{|c|}{ Restrictive Sample } & \multicolumn{2}{|c|}{ Non-restrictive Sample } \\
\hline & $(1)$ & $(2)$ & $(3)$ & $(4)$ \\
\hline \multirow[t]{2}{*}{1 if Voluntary $\mathrm{JC}$} & $0.049^{*}$ & $0.045^{*}$ & $0.088^{* * *}$ & $0.065^{* * *}$ \\
\hline & $(0.026)$ & $(0.024)$ & $(0.021)$ & $(0.021)$ \\
\hline \multirow[t]{2}{*}{1 if Voluntary JC risk-averse } & 0.011 & 0.022 & 0.055 & $0.05^{*}$ \\
\hline & $(0.045)$ & $(0.038)$ & $(0.034)$ & $(0.03)$ \\
\hline \multirow[t]{2}{*}{ Experience } & & $0.090^{* * *}$ & & $0.087^{* * *}$ \\
\hline & & $(0.011)$ & & $(0.010)$ \\
\hline \multirow[t]{2}{*}{ Experience square } & & $-0.003^{* *}$ & & $-0.02^{*}$ \\
\hline & & $(0.001)$ & & $(0.01)$ \\
\hline \multirow[t]{2}{*}{ Tenure } & & 0.004 & & $0.018^{* * *}$ \\
\hline & & $(0.006)$ & & $(0.005)$ \\
\hline Occupation dummies & \multicolumn{3}{|c|}{$\sqrt{ }$} & $\sqrt{ }$ \\
\hline Industry dummies & \multicolumn{3}{|c|}{$\sqrt{ }$} & $\sqrt{ }$ \\
\hline Within R-squared & 0.006 & 0.311 & 0.021 & 0.230 \\
\hline Between R-squared & 0.002 & 0.010 & 0.009 & 0.180 \\
\hline Overall R-squared & 0.002 & 0.103 & 0.001 & 0.196 \\
\hline Observations (person) & \multicolumn{2}{|c|}{165} & \multicolumn{2}{|c|}{504} \\
\hline Observations (person*year) & \multicolumn{2}{|c|}{1155} & \multicolumn{2}{|c|}{2608} \\
\hline
\end{tabular}

Source: SOEP 1992-2013. Sample: Labour market entrants (aged 18-32 at the time of entry) during their first seven years in the labour market.

Notes: Estimation Method: Fixed Effects Panel Estimation. Dependent variable: Monthly real wage. Model: Fixed effect regression. Sample only contains job changers. Standard errors are in parentheses. ${ }^{* * *},{ }^{*},{ }^{*}$ denote significance at the 0.01 , 0.05 and 0.10 levels.

Secondly, it could be that the composition of individuals in the two samples are not comparable when it comes to measuring wage differences. The descriptive figures in Table B.2 indicate that there are differences in labour attachment such that individuals in the non-restrictive sample are less educated, have lower tenure and less favourable conditions in the first job. Yet those differences should reflect an individuals time-invariant capability to be successful on the labour market which is accounted for by the estimation technique independent of the sample composition. Note also that we do not find any structural differences in the relationship between risk attitudes and job changing behaviour using either the restrictive or the non-restrictive sample (see Section 4.1).

We therefore conclude that differences in the estimation results can be ascribed to insufficient variation (or insufficient sample size) of the restrictive sample but not to differences in the composition between the two samples. Hence, in summary, we find that risk-averse individuals tend to obtain on average higher wage growth with each job change made.

Table 4 presents evidence pertaining to the influence of risk attitudes on the difference in overall 
wage growth related to job changing behaviour. We aim at answering the question whether the difference in the number of job changes between risk-averse and risk-tolerant individuals results in different overall wage growth after seven years in the labour market.

Table 4: Influence of risk attitudes on the relationship between job change and overall wage growth

\begin{tabular}{|c|c|c|c|c|c|c|}
\hline & \multicolumn{3}{|c|}{ Restrictive Sample } & \multicolumn{3}{|c|}{ Non-restrictive Sample } \\
\hline & (1) & $(2)$ & (3) & $(4)$ & $(5)$ & (6) \\
\hline \multirow[t]{2}{*}{1 if Risk-averse } & -0.046 & -0.077 & -0.062 & -0.040 & -0.040 & -0.039 \\
\hline & $(0.064)$ & $(0.072)$ & $(0.074)$ & $(0.030)$ & $(0.030)$ & $(0.030)$ \\
\hline \multirow[t]{2}{*}{ No. of job changes } & 0.033 & 0.043 & 0.038 & $0.051^{* *}$ & $0.045^{*}$ & 0.041 \\
\hline & $(0.036)$ & $(0.036)$ & $(0.035)$ & $(0.025)$ & $(0.025)$ & $(0.025)$ \\
\hline \multirow[t]{2}{*}{ Risk-averse*No. job changes } & $0.111^{*}$ & $0.120^{*}$ & 0.105 & $0.087^{* *}$ & $0.079 *$ & $0.080^{*}$ \\
\hline & $(0.065)$ & $(0.070)$ & $(0.071)$ & $(0.042)$ & $(0.041)$ & $(0.042)$ \\
\hline \multirow[t]{2}{*}{1 if Male } & & -0.019 & -0.016 & & 0.026 & 0.028 \\
\hline & & $(0.048)$ & $(0.050)$ & & $(0.027)$ & $(0.027)$ \\
\hline \multirow[t]{2}{*}{1 if Originates from West Germany } & & 0.084 & 0.064 & & 0.052 & 0.040 \\
\hline & & $(0.074)$ & $(0.076)$ & & $(0.032)$ & $(0.033)$ \\
\hline \multirow[t]{2}{*}{1 if German national } & & 0.018 & 0.011 & & $0.092^{* *}$ & 0.068 \\
\hline & & $(0.072)$ & $(0.080)$ & & $(0.042)$ & $(0.043)$ \\
\hline \multirow[t]{2}{*}{1 if Low or no educational degree } & & -0.107 & $-0.110^{*}$ & & -0.006 & -0.002 \\
\hline & & $(0.067)$ & $(0.063)$ & & $(0.040)$ & $(0.040)$ \\
\hline \multirow[t]{2}{*}{1 if Tertiary educational degree } & & -0.020 & -0.034 & & 0.017 & -0.008 \\
\hline & & $(0.082)$ & $(0.086)$ & & $(0.042)$ & $(0.043)$ \\
\hline \multirow[t]{2}{*}{ Age starting first job } & & 0.006 & 0.001 & & 0.001 & -0.003 \\
\hline & & $(0.012)$ & $(0.013)$ & & $(0.006)$ & $(0.006)$ \\
\hline \multirow[t]{2}{*}{ Constant } & $0.340^{* * *}$ & -0.132 & 0.047 & $0.330^{* * *}$ & 0.042 & 0.136 \\
\hline & $(0.043)$ & $(0.304)$ & $(0.318)$ & $(0.032)$ & $(0.211)$ & $(0.217)$ \\
\hline Year dummies & & $\sqrt{ }$ & $\sqrt{ }$ & & $\sqrt{ }$ & $\sqrt{ }$ \\
\hline Parental background & & & $\sqrt{ }$ & & & $\sqrt{ }$ \\
\hline Employment gap dummies & & & & $\sqrt{ }$ & $\sqrt{ }$ & $\sqrt{ }$ \\
\hline R-squared & 0.032 & 0.089 & 0.111 & 0.096 & 0.113 & 0.127 \\
\hline Sample & 280 & 280 & 280 & 1370 & 1370 & 1370 \\
\hline
\end{tabular}

Source: SOEP. Sample: labour market entrants. Dependent variable: over all wage growth measures as the difference between the wage in the job held in the seventh year after entering the labour market and the wage in the first job.

Notes: Estimation Method: OLS. Heteroscedasticity-consistent standard errors are in parentheses. ${ }^{* *},{ }^{* *},{ }^{*}$ denote significance at the $0.01,0.05$, and 0.10 levels.

We find that the patterns of job mobility (measured by the number of job changes during early career) lead to weakly significant difference in overall wage growth for risk-averse and risk-tolerant individuals. Overall, risk-averse individuals tend to obtain higher overall wage growth through their job changing behaviour. Interestingly, the base effect of risk attitudes (partialling out the number of job changes) shows no significant influence on overall wage growth throughout the specifications. As a tentative conclusion from this finding, job mobility can be considered the channel through which risk attitudes influence wage growth.

To sum up our empirical results, risk-averse individuals change their jobs less often during early career. If they change their job, they tend to obtain on average higher wage growth accompanied 
with the job change. Overall risk-averse individuals end up with moderate higher wage growth during early career. This last result could be interpreted in the way that risk-averse individuals manage to obtain higher wage gains from the joint decision of how many times to change the job and which job to take (with respect to wages).

\section{Conclusion}

Deciding to change the job is risky because it entails significant costs while benefits cannot be entirely foreseen. In this study, we therefore present a theoretical model on the relationship between risk attitudes and job mobility. According to the theoretical prediction, the more risk-averse individuals are the less likely they change their job. Subsequently, we propose that the relationship between risk attitudes and job mobility is responsible for different patterns in wage growth during early career. Using SOEP data we indeed find that risk-averse individuals change their jobs significantly less often during early career. Furthermore, wage growth associated with each job change tends to be higher for risk-averse individuals than for risk-tolerant individuals. Lastly, overall wage growth measured by the difference between the wage level in the first job and in the job held after seven years in the labour market moderately differs between risk-averse and risk-tolerant individuals. The job changing behaviour during early career leads to higher wage growth for risk-averse individuals. A number of sensitivity tests including sample composition, econometric specification and measurement of risk attitudes confirm the robustness of our main findings.

Our findings provide an alternative explanation for the influence of risk attitudes as an individual's productivity trait on wage growth. While risk attitudes can influence wage growth through the decision to invest in human capital (Shaw, 1996) or through the decision for an occupational environment with specific wage structure (Bonin et al., 2007; Skriabikova et al., 2014), we find some evidence that risk attitudes matter for wage growth through mobility decisions. Our empirical findings are therefore relevant for labour market research which studies groups with pronounced differences in risk attitudes. For instance, empirical evidence shows that there is heterogeneity in willingness to take risks between men and women (Dohmen et al., 2011) as well as between native and migrants (Bonin et al., 2009). Our finding that risk attitude is a crucial behavioural trait that influences individuals' job mobility decisions can help to explain existing wage gaps between those groups.

Our measure of job changes may not comprise all the risks inherent to job changes. In particular, some job changes in our sample might have been job changes within the same firm, which entails less uncertainty than a job change to another employer. Job mobility in our analysis might therefore overestimate the associated risks. Our estimates of the effect of risk attitude on job mobility and the subsequent wage growth can thus be considered a lower bound. 
For future research it would be interesting to disentangle the antagonising effects of job-specific human capital accumulation and of improvement in match quality through job changes, and to examine their role for differences in early career wage growth. We do not find a significant difference between the two groups of risk-averse and risk-tolerant individuals with respect to the timing of job changes which determines job tenure. To further investigate returns to tenure and returns to information on match quality, data with information on wages and job changes on a monthly basis is needed.

It would also be interesting for future work to investigate the influence of risk attitude on job search intensity and to consider the resulting heterogeneity in wage growth. Job search intensity or job mobility intentions may also be related to risk attitudes as the costs and benefits of on-the-job search are similarly uncertain for individuals than it applies to actual job changes. 


\section{A References}

Andersen, S., Harrison, G. W., Lau, M. I., and Rutström, E. E. (2008). Lost in state space: are preferences stable? International Economic Review, 49(3):1091-1112.

Angrist, J. D. and Pischke, J. (2009). Mostly harmless econometrics: An empiricist's companion. Princeton University Press.

Antonovics, K. and Golan, L. (2012). Experimentation and job choice. Journal of Labor Economics, 30(2):333-366.

Bartel, A. P. and Borjas, G. J. (1981). Wage growth and job turnover: An empirical analysis. In S., R., editor, Studies in Labor Market. The University of Chicago Press, Chicago.

Baucells, M. and Villasís, A. (2009). Stability of risk preferences and the reflection effect of prospect theory. Theory and Decision, 68(1-2):193-211.

Bonhomme, S. and Jolivet, G. (2009). The pervasive absence of compensating differentials. Journal of Applied Econometrics, 24(5):763-795.

Bonhomme, S., Jolivet, G., and Leuven, E. (2015). School characteristics and teacher turnover: Assessing the role of preferences and opportunities. The Economic Journal, forthcoming.

Bonin, H., Constant, A. F., Tatsiramos, K., and Zimmermann, K. F. (2009). Native-migrant differences in risk attitudes. Applied Economics Letters, 16 (15):1581-1586.

Bonin, H., Dohmen, T., Falk, A., Huffman, D., and Sunde, U. (2007). Cross-sectional earnings risk and occupational sorting: The role of risk attitudes. Labour Economics, 14:926-937.

Bono, E. D. and Vuri, D. (2011). Job mobility and the gender wage gap in italy. Labour Economics, 18:130-142.

Brown, S. and Taylor, K. (2005). Wage growth, human capital and financial investment. The Manchester School, 73(6):686-708.

Budria, S., Diaz-Serrano, L., Ferrer-i-Carbonell, A., and Hartog, J. (2012). Risk attitude and wage growth: Replicating Shaw (1996). Empirical Economics, 44 (2):981-1004.

Burdett, K. (1978). A Theory of Employee Job Search and Quit Rates. The American Economic Review, 68(1):212-220.

Caliendo, M., Fossen, F. M., and Kritikos, A. S. (2009). Risk Attitudes of Nascent Entrepreneurs New Evidence from an Experimentally Validated Survey. Small Business Economics, 32(2):153167.

Dohmen, T., Falk, A., Huffman, D., and Sunde, U. (2012a). The intergenerational transmission of risk and trust attitudes. Review of Economic Studies, 79(2):645-677.

Dohmen, T., Falk, A., Huffman, D., Sunde, U., Schupp, J., and Wagner, G. G. (2011). Individual Risk Attitudes: Measurement, Determinants, and Behavioral Consequences. Journal of the European Economic Association, 9(3):522-550.

Dohmen, T., Falk, A., Huffman, D., Sunde, U., Schupp, J., and Wagner, G. G. (2012b). The Measurement and Stability of Risk Preferences. Maastricht University, mimeo.

Dustmann, C. and Meghir, C. (2005). Wages, experience and seniority. Review of Economic Studies, 72:77-108. 
Farber, H. S. and Gibbons, R. (1996). Learning and wage dynamics. The Quarterly Journal of Economics, 111(4):1007-1047.

Fossen, F. M. (2011). The Private Equity Premium Puzzle Revisited: New Evidence on the Role of Heterogeneous Risk Attitudes. Economica, 78:656-675.

Fuchs-Schündeln, N. and Schündeln, M. (2005). Precautionary savings and Self-Selection: Evidence from the German Reunification Experiment. The Quarterly Journal of Economics, 120(3):10851120 .

Fuller, S. (2008). Job Mobility and Wage Trajectories for Men and Women in the United States. American Sociological Review, 73:158-183.

Harrison, G. W., Johnson, E., McInnes, M. M., and Rutström, E. E. (2005). Temporal stability of estimates of risk aversion. Applied Financial Economics Letters, 1(1):31-35.

Hunt, J. (2001). Post-unification wage growth in East Germany. The Review of Economics and Statistics, pages 190-195.

Hwang, H., Mortensen, D. T., and Reed, W. R. (1998). Hedonic wages and labor market search. Journal of Labor Economics, 16(4):815-847.

Johnson, W. R. (1978). A Theory of Job Shopping. Quarterly Journal of Economics, 92(2):261-277.

Jovanovic, B. (1979a). Firm-specific Capital and Turnover. Journal of Political Economy, 87(6):12461260.

Jovanovic, B. (1979b). Job matching and the theory of turnover. Journal of Political Economy, 87(5):972-990.

Light, A. and McGarry, K. (1998). Job change patterns and the wages of young men. The Review of Economics and Statistics, 80(2):276-286.

Manning, A. and Swaffield, J. (2008). The gender gap in early-career wage growth. The Economic Journal, 118(530):983-1024.

McGoldrick, K. and Robst, J. (1996). The effect of worker mobility on compensating wages for earnings risk. Applied Economics, 28(2):221-232.

Möller, J. and Umkehrer, M. (2014). Are there long-term earnings scars from youth unemployment in Germany? ZEW Discussion Paper 2014-089.

Mortensen, D. (1986). Job search and labor market analysis. In Ashenfelter, O., L. R., editor, Handbook of Labor Economics. North-Holland, Amsterdam.

Necker, S. and Voskort, A. (2014). Intergenerational transmission or risk attitudes - A revealed preference approach. European Economic Review, 65:66-89.

Neumark, D. (2002). Youth labor markets in the united states: Shopping around vs. staying put. The Review of Economics and Statistics, 84(3):462-482.

Papageorgiou, T. (2014). Learning your comparative advantage. The Review of Economic Studies, 81(3):1263-1295.

Pavlopoulos, D., Fouarge, D., Muffels, R., and Vermunt, J. (2014). Who benefits from a job change: The dwarfs or the giants? European Societies, 16(2):299-319.

Perez, J. I. G. and Sanz, Y. R. (2005). Wage Changes Through Job Mobility in Europe: A Multinomial Endogenous Switching Approach. Labour Economics, 12:531-555. 
Pfeifer, C. (2010). Risk aversion and sorting into public sector employment. German Economic Review, 12(1):85-99.

Reynaud, A. and Couture, S. (2010). Stability of Risk Preference Measures: Results From a Field Experiment on French Farmers.

Sahm, C. (2007). How Much Does Risk Tolerance Change? Federal Reserve Board, Washington, D.C.: Finance and Economics Discussion Series.

Shaw, K. L. (1996). An empirical analysis of risk aversion and income growth. Journal of Labor Economics, 14(4):626-653.

Skriabikova, O., Dohmen, T., and Kriechel, B. (2013). Risk attitudes and occupational choice: Evidence from an era of evolving heterogeneity in occupation-specific earnings risk. mimeo.

Skriabikova, O., Dohmen, T., and Kriechel, B. (2014). New evidence on the relationship between risk attitudes and self-employment. Labour Economics, 30:176-184.

Sullivan, P. and To, T. (2014). Search and nonwage job characteristics. Journal of Human Resources, 49(2):472-507.

Topel, R. H. and Ward, M. P. (1992). Job mobility and the careers of young men. The Quarterly Journal of Economics, 107(2):439-479.

van den Berg, G. (1992). A structural dynamic analysis of job turnover and the costs associated with moving to another job. The Economic Journal, 102:1116-1133.

von Wachter, T. and Bender, S. (2006). In the right place at the wrong time: The role of firms and luck in young workers' careers. American Economic Review, 96(5):1679-1705.

Wagner, G. G., Frick, J. R., and Schupp, J. (2007). The german socio-economic panel study (soep) - scope, evolution and enhancements. Schmollers Jahrbuch, 127 (1):139-169. 


\section{B Appendix}

Table B.1: Sample selection procedure

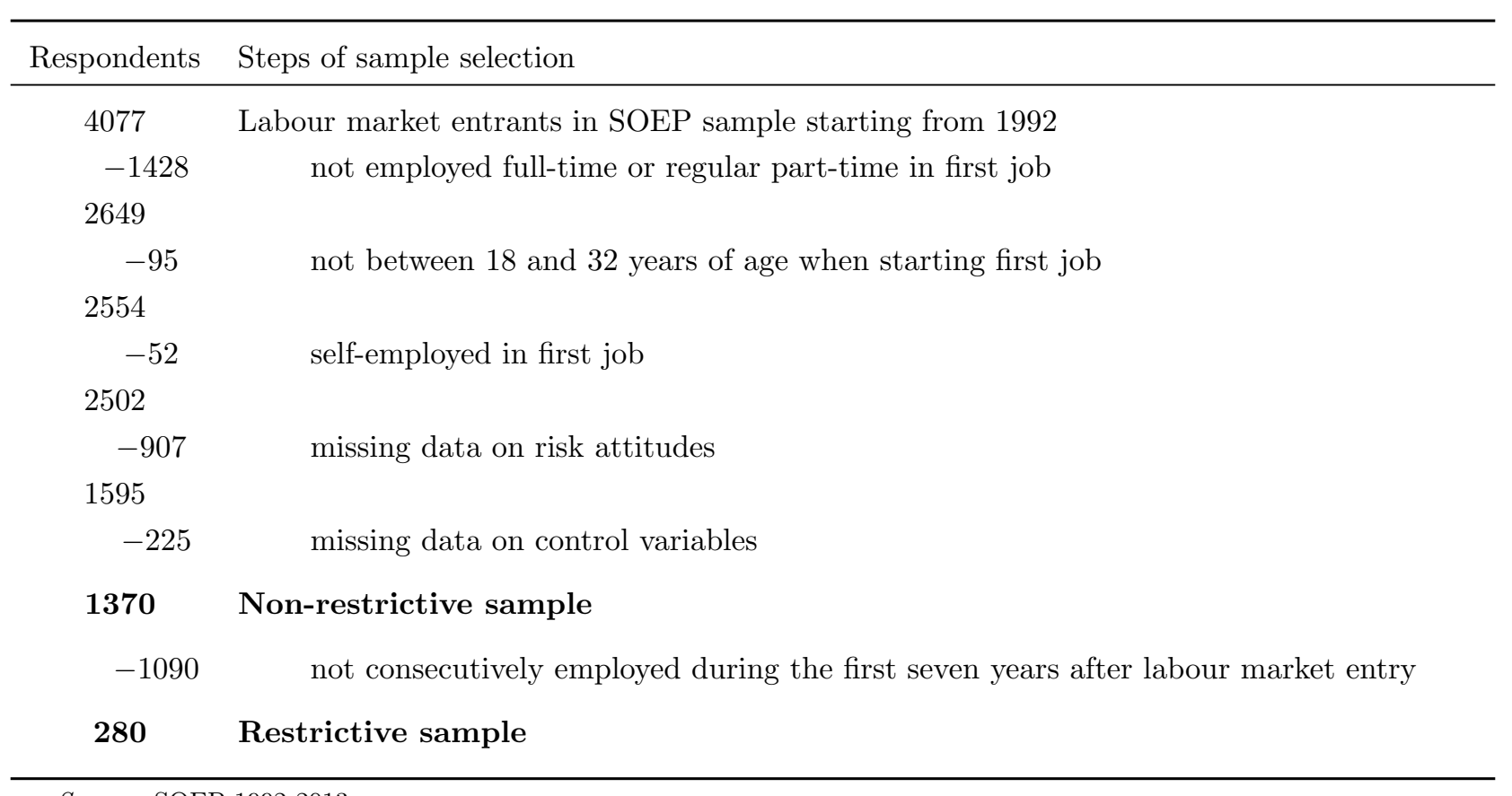

Source: SOEP 1992-2013 
Table B.2: Descriptive statistics

\begin{tabular}{|c|c|c|c|c|c|c|c|c|}
\hline & \multicolumn{4}{|c|}{ Restrictive sample } & \multicolumn{4}{|c|}{ Nonrestrictive sample } \\
\hline & \multicolumn{4}{|c|}{ (1) } & \multicolumn{4}{|c|}{$(2)$} \\
\hline & Mean & $\mathrm{SD}$ & Min & Max & Mean & $\mathrm{SD}$ & Min & $\operatorname{Max}$ \\
\hline 1 if at least one job change & 0.59 & 0.49 & 0 & 1 & 0.37 & 0.48 & 0 & 1 \\
\hline Number of job changes & 0.83 & 0.84 & 0 & 4 & 0.49 & 0.75 & 0 & 4 \\
\hline Number of job changes (at least one) & 1.40 & 0.62 & 1 & 4 & 1.34 & 0.61 & 1 & 4 \\
\hline Risk attitude & 4.85 & 2.42 & 0 & 10 & 4.52 & 2.43 & 0 & 10 \\
\hline 1 if Risk-averse & 0.39 & 0.49 & 0 & 1 & 0.43 & 0.50 & 0 & 1 \\
\hline 1 if Male & 0.51 & 0.50 & 0 & 1 & 0.47 & 0.50 & 0 & 1 \\
\hline 1 if living in West Germany & 0.78 & 0.42 & 0 & 1 & 0.73 & 0.44 & 0 & 1 \\
\hline 1 if German nationality & 0.89 & 0.32 & 0 & 1 & 0.89 & 0.31 & 0 & 1 \\
\hline \multicolumn{9}{|l|}{ Degree (Intermediate degree) } \\
\hline 1 if Low or no educational degree & 0.09 & 0.28 & 0 & 1 & 0.17 & 0.38 & 0 & 1 \\
\hline 1 if Tertiary educational degree & 0.30 & 0.46 & 0 & 1 & 0.22 & 0.41 & 0 & 1 \\
\hline Age starting first job & 23.58 & 3.15 & 19 & 32 & 23.31 & 3.05 & 18 & 32 \\
\hline Job satisfaction in first job & 7.42 & 1.94 & 1 & 10 & 7.24 & 1.98 & 0 & 10 \\
\hline 1 if First job in public sector & 0.27 & 0.44 & 0 & 1 & 0.24 & 0.43 & 0 & 1 \\
\hline 1 if Permanent contract in first job & 0.59 & 0.49 & 0 & 1 & 0.50 & 0.50 & 0 & 1 \\
\hline 1 if Part-time employment in first job & 0.09 & 0.29 & 0 & 1 & 0.17 & 0.38 & 0 & 1 \\
\hline Tenure in first job & 1.58 & 1.48 & 0.0 & 6.6 & 1.37 & 1.36 & 0.0 & 6.60 \\
\hline Wage variation within occ. in first job & 0.51 & 0.09 & 0.2 & 0.7 & 0.54 & 0.09 & 0.19 & 0.84 \\
\hline Log of monthly wage in first job & 7.22 & 0.44 & 5.63 & 8.22 & 7.00 & 0.61 & 4.54 & 8.40 \\
\hline Observations & 280 & & & & 1370 & & & \\
\hline
\end{tabular}

Notes: SD stands for standard deviation. Sample: Labour market entrants (aged 18-32 at the time of entry) during their first seven years.

Source: SOEP 1992-2013. 